\begin{tabular}{|c|c|}
\hline 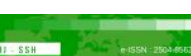 & Malaysian Journal of Social Sciences and Humanities (MJSSH) \\
\hline Malaysian Journal of & Volume 5, Issue 11, November 2020 \\
\hline (MJ-SSH) & e-ISSN : 2504-8562 \\
\hline & $\begin{array}{l}\text { Journal home page: } \\
\text { www.msocialsciences.com }\end{array}$ \\
\hline
\end{tabular}

\title{
Sokongan Sosial, Penghargaan Kendiri dan Kemurungan dalam kalangan Mahasiswa di Universiti
}

\author{
Azlina Mohd Khir¹, Nor Aina Syahira Rodzuwan'1, Amna Md. Noor¹, Wan Munira Wan Jaafar1 \\ \& Mohammad Mujaheed Hassan ${ }^{1}$
}

${ }^{1}$ Jabatan Sains Kemasyarakatan dan Pembangunan, Fakulti Ekologi Manusia, Universiti Putra Malaysia (UPM)

Correspondence: Azlina Mohd Khir (m_azlina@upm.edu.my)

\begin{abstract}
Abstrak
Kajian ini bertujuan untuk menentukan hubungan antara sokongan sosial, penghargaan kendiri dan kemurungan dalam kalangan mahasiswa di Universiti Putra Malaysia. Seramai 234 responden $(37.2 \%$ lelaki dan $62.8 \%$ perempuan; $50 \%$ pelajar sains dan 50\% pelajar sains sosial) terlibat dalam kajian ini. Responden dipilih melalui kaedah persampelan pelbagai peringkat. Satu set borang soal selidik yang diedar kepada responden mengandungi tiga komponen iaitu Multidimensional Scale of Perceived Social Support (MSPSS), Rosernberg Self Esteem Scale (RSES) dan Beck Depression Inventory II (BDI II). Analisis statistik yang digunakan adalah ujian-t, korelasi Peason, dan regresi. Hasil kajian menunjukkan bahawa tahap sokongan sosial dan penghargaan kendiri responden berada pada tahap yang sederhana, manakala tahap kemurungan menunjukkan majoriti responden berada pada tahap yang normal. Keputusan analisis ujian-t menunjukkan tidak terdapat perbezaan yang signifikan tahap kemurungan berdasarkan jantina dan program pengajian. Manakala keputusan analisis korelasi Pearson menunjukkan terdapat hubungan negatif secara signifikan antara kesemua dimensi sokongan sosial dan penghargaan kendiri dengan kemurungan $(r=-0.391$ hingga $-0.510 ; p<0.01)$. Dapatan kajian bagi analisis regresi menunjukkan pengaruh yang signifikan antara pemboleh ubah peramal iaitu sokongan sosial (keluarga dan rakan-rakan) dan penghargaan kendiri terhadap kemurungan $(\beta=-0.177$ hingga -0.301$)$. Kesimpulannya, sokongan sosial dan penghargaan kendiri merupakan peramal kepada kemurungan dalam kalangan mahasiswa UPM yang dikaji. Justeru, untuk mengurangkan tahap kemurungan, faktor sokongan sosial dan penghargaan kendiri memainkan peranan yang penting.
\end{abstract}

Kata kunci: sokongan sosial, penghargaan kendiri, kemurungan, mahasiswa

\section{Social Support, Self-Esteem and Depression among University Students}

\begin{abstract}
This study aims to determine the relationships between social support, self-esteem, and depression among Universiti Putra Malaysia students. A total of 234 respondents (37.2 \% male and $62.8 \%$ female, $50 \%$ science students and 50\% social science students) involved in this study. Respondents were selected through multi-stage sampling technique. A set of questionnaires distributed to the respondents consisted of three instruments namely Multidimensional Scale of Perceived Social Support (MSPSS), Rosernberg Self-Esteem Scale (RSES) and Beck Depression Inventory II (BDI II). Statistical analysis used are t-test, Peason correlation, and regression. Findings revealed that the level of social support and self-esteem of
\end{abstract}


respondents were moderate, meanwhile depression level showed majority of respondents were normal. The results of t-test analysis showed that there were no significant differences of depression based on sex and program studies. Moreover, Pearson correlation analysis found negative relationships between social supports and self-esteem with depression $(r=-0.391$ to $-0.510 ; \mathrm{p}<0.01)$. The findings of the regression analysis revealed that there were significant influence between predictor variables which are social support (family and friends) and self-esteem with depression. In conclusion, social support and self-esteem are predictors of depression among UPM students. Hence, to reduce the level of depression, social support and self-esteem factors play an important role.

Keywords: social support, self-esteem, depression, undergraduate students

\section{Pengenalan}

Kemurungan adalah gangguan perasaan yang menyebabkan seseorang individu itu merasa sedih yang berpanjangan, keletihan dan ketiadaan tenaga, cepat marah serta hilang minat dalam aktiviti harian. Kemurungan boleh dihidapi oleh sesiapa sahaja tidak kira umur, jantina atau bangsa. Kemurungan berlarutan sekurang-kurangnya dalam masa dua minggu dan boleh berlangsung sehingga berbulanbulan atau bertahun-tahun (Kementerian Kesihatan Malaysia, 2012). Menurut Pertubuhan Kesihatan Sedunia (WHO, 2018), kemurungan dikategorikan sebagai satu penyakit yang biasa dihadapi oleh masyarakat seluruh dunia, dengan lebih daripada 300 juta orang berhadapan dengan gejala ini. Di Malaysia, Tinjauan Kesihatan dan Morbiditi Kebangsaan (2019) mendapati prevalen kemurungan ialah 18.3 peratus, di mana seorang daripada 5 orang remaja mengalami gejala kemurungan, 2 daripada 5 orang mengalami keresahan dan 1 daripada 10 orang mengalami stres.

Kemurungan adalah berbeza dengan keadaan emosi yang turun naik atau tindak balas emosi terhadap sesuatu cabaran dalam kehidupan (Aini Azeqa \& Haslinda, 2019). Namun, apabila emosi ini tidak dikawal, ia akan membawa kepada kemurungan tahap sederhana malahan tinggi, dan seterusnya boleh mendatangkan masalah kesihatan yang serius. Antara simptom kemurungan ialah perasaan kesedihan atau kekosongan yang berpanjangan, hilang minat terhadap hobi yang biasanya mendatangkan keseronokan, cepat rasa letih dan tidak bertenaga, perasaan mudah putus asa, bersalah, rasa diri tidak berguna, rasa tidak tenteram dan mudah marah, kurang daya tumpuan dan ingatan, mudah cemas dan gelisah. Selain itu, pesakit juga mengalami gangguan tidur, hilang selera makan, sakit kepala, sakit-sakit badan dan gangguan penghadaman serta membawa kepada percubaan bunuh diri. Berdasarkan laporan oleh Pertubuhan Kesihatan Sedunia (2018), hampir 800,000 orang dilaporkan mati akibat bunuh diri setiap tahun yang majoritinya berusia 15 hingga 29 tahun.

Disebabkan kemurungan berhubung dengan peningkatan risiko bunuh diri, tingkah laku kesihatan yang lemah, kefungsian yang terjejas dan bebanan kepada keluarga (Thapar, Collishaw, Pine \& Thapar, 2012; Zheng \& Zheng, 2015), maka keperluan segera untuk membentuk pencegahan dan kaedah intervensi yang efektif perlu dilakukan untuk mengatasi dan merawat kemurungan (Chang, Yuan \& Chen, 2018). Untuk itu, pengenalpastian kepada faktor-faktor yang menyebabkan kemurungan adalah penting untuk diketahui. Hasil penemuan penyelidik-penyelidik terdahulu terhadap faktor yang mendorong terjadinya masalah kemurungan ini ialah sejarah keluarga yang pernah mengalami kemurungan, kanak-kanak yang terabai atau didera, peristiwa kehidupan yang penuh tekanan dan sakit kronik seperti penderita kanser (Bhatia \& Bhatia, 2007) serta kegagalan mengenal identiti diri (Bios, 1988), rasa tidak selamat (Armsden, McCauley, Greenberg, Burke \& Mitchell, 1990), pengaruh keibubapaan (King, 1995) dan masalah persekitaran (Blatt, Wein, Chevron \& Quinlan, 1999).

Menurut Cornwell (2003) dan Sherina, Afiah dan Shamsul (2003), terdapat hubungan yang signifikan antara masalah kemurungan dengan tahap pendidikan. Individu yang mempunyai tahap pendidikan yang tinggi lebih cenderung untuk mengalami kemurungan berbanding individu yang mempunyai tahap pendidikan yang rendah. Ini bermakna, mahasiswa yang melanjutkan pelajaran di peringkat tertiari mempunyai kecenderungan untuk mengalami kemurungan. Dalam kesibukan di kampus untuk 
mempersiapkan diri sebagai graduan kelak, mahasiswa terdedah kepada pelbagai cabaran terutamanya berkaitan pembelajaran, tugasan, peperiksaan dan pelbagai aktiviti kokurikulum. Cabaran-cabaran tersebut memberi sedikit tekanan kepada para pelajar dan sekiranya tekanan tidak dapat diatasi, maka pelajar akan terdedah kepada masalah kemurungan. Ini disokong oleh Brown, Andrews, Harris, Adler dan Bridge (1986) yang mendapati risiko kemurungan akan meningkat apabila individu berada dalam tekanan.

Kajian yang dijalankan oleh Chang, Yuan dan Chen (2018) ke atas remaja di China mendapati sokongan ibu bapa dan kawan-kawan berhubung secara langsung dengan tahap kemurungan. Remaja yang kurang mendapat sokongan sosial cenderung untuk mengalami kemurungan, manakala yang mendapat sokongan sosial yang tinggi daripada keluarga dan rakan-rakan dapat mengurangkan tahap kemurungan. Sokongan sosial merujuk kepada penyediaan kedua-dua sumber material dan psikologikal dengan hasrat untuk membantu seseorang mengatasi tekanan (Chu, Saucier \& Hafner, 2010, p.625). Sokongan sosial juga didefinisikan sebagai hubungan interpersonal dan sokongan yang diberikan oleh institusi sosial yang bertujuan memberi kesejahteraan kepada individu (Costello, Pickens \& Fenton, 2001). Sumber utama sokongan sosial bagi remaja termasuklah keluarga, rakan sebaya dan guru sekolah (Rosenfeld, Richman \& Bowen, 2000). Sokongan sosial daripada keluarga dan rakan-rakan adalah penting dalam menyumbang kepada kesihatan psikologikal yang positif dalam kalangan remaja.

Persepsi remaja terhadap sokongan sosial keluarga mahupun rakan-rakan menyumbang kepada hasil perkembangan yang positif. Walau bagaimanapun, remaja cenderung untuk mempersepsikan sokongan sosial secara berbeza dalam perhubungan bersama keluarga dan rakan-rakan (Procidano \& Heller, 1983). Berdasarkan model kesan sokongan sosial, iaitu teori psikososial dalam menerangkan kenapa individu menderitai masalah kesihatan mental, individu yang merasakan dirinya kurang sokongan sosial lebih menderitai kemurungan (Cohen \& Wills, 1985).

Selain daripada faktor sokongan sosial, faktor dalaman seperti penghargaan kendiri juga menyumbang kepada kemurungan dalam kalangan remaja mahupun belia. Penghargaan kendiri merujuk kepada suatu bentuk penilaian yang bersifat positif atau negatif terhadap diri sendiri (Feshbach, Weiner \& Bohart, 1996). Di samping itu, penghargaan kendiri juga menunjukkan tahap seseorang individu berasa yakin terhadap diri sendiri sebagai individu yang mempunyai keyakinan, bernilai dan penting (Muhd Mansur \& Siti Nordinar, 1998). Menurut Marsh (1993), pelajar yang mempunyai penghargaan kendiri yang tinggi akan lebih berjaya berbanding pelajar yang memiliki penghargaan kendiri yang rendah. Penilaian yang negatif terhadap diri iaitu penghargaan kendiri yang rendah dan kekurangan sokongan berkait dengan peningkatan risiko kemurungan apabila individu berada dalam tekanan (Brown, Andrews, Harris, Adler \& Bridge, 1986). Selain itu, Siti Rohana (2004) turut mendapati hubungan yang signifikan antara penghargaan kendiri dengan kemurungan dalam kalangan belia. Peningkatan penghargaan kendiri dapat mengurangkan kemungkinan penderitaan kesan psikologikal yang negatif seperti kemurungan (Lee, Dickson, Conley \& Holmbeck, 2014).

Berdasarkan faktor-faktor yang telah dikenal pasti, maka dapat memberi input dalam membendung isu kemurungan dalam kalangan masyarakat amnya. Menyedari hakikat di atas, penyelidik melihat kajian berkenaan kemurungan dan faktor-faktor yang menyumbang kepadanya dalam kalangan mahasiswa wajar dikaji dan relevan supaya masyarakat sedar dan lebih peka dengan isu yang berkaitan dengan kesihatan mental di samping membantu individu yang mengalami tekanan dan kemurungan untuk mengatasi masalah yang dihadapi dengan lebih berkesan.

\section{Objektif Kajian dan Hipotesis}

Kajian ini bertujuan untuk menentukan hubungan antara sokongan sosial, penghargaan kendiri dan kemurungan dalam kalangan mahasiswa di UPM. Objektif khusus kajian adalah untuk:

i. Mengenal pasti tahap sokongan sosial, penghargaan kendiri dan kemurungan dalam kalangan mahasiswa;

ii. Menentukan perbezaan tahap kemurungan dalam kalangan responden berdasarkan jantina dan bidang pengajian; 
DOI: https://doi.org/10.47405/mjssh.v5i11.547

iii. Menentukan hubungan antara sokongan sosial, penghargaan kendiri dan kemurungan dalam kalangan mahasiswa; dan

iv. Menentukan faktor peramal kemurungan dalam kalangan mahasiswa.

Berdasarkan tinjauan literatur dan objektif kajian yang telah dinyatakan, maka hipotesis yang telah dibina adalah seperti berikut:

Ho1: $\quad$ Tidak terdapat perbezaan yang signifikan tahap kemurungan berdasarkan jantina.

Ho2: Tidak terdapat perbezaan yang signifikan tahap kemurungan berdasarkan program pengajian.

Ho3: Tidak terdapat hubungan yang signifikan antara sokongan sosial (keluarga) dan kemurungan.

Ho4: Tidak terdapat hubungan yang signifikan antara sokongan sosial (rakan-rakan) dan kemurungan.

Ho5: Tidak terdapat hubungan yang signifikan antara sokongan sosial (pihak lain yang penting) dan kemurungan.

Ho6: Tidak terdapat hubungan yang signifikan antara penghargaan kendiri dan kemurungan.

Ho7: Tidak terdapat pengaruh yang signifikan antara pemboleh ubah peramal iaitu sokongan sosial (keluarga, rakan-rakan dan pihak lain yang penting) dan penghargaan kendiri dengan kemurungan.

\section{Metod Kajian}

\section{Rekabentukdan Lokasi Kajian}

Kajian ini merupakan kajian kuantitatif dan keratan rentas, dengan menggunakan rekabentuk korelasi. Kajian ini dijalankan untuk mengkaji hubungan antara sokongan sosial, penghargaan kendiri dan kemurungan dalam kalangan mahasiswa di UPM.

\section{Sampeldan Teknik Persampelan}

Kajian ini melibatkan 234 orang mahasiswa di UPM. Responden dipilih melalui teknik persampelan pelbagai peringkat. Peringkat pertama ialah pemilihan fakulti yang dilakukan secara persampelan rawak berkelompok berdasarkan kategori bidang sains sosial dan sains. Dua program pengajian yang berbeza dipilih secara rawak adalah untuk menguji perbezaan tahap kemurungan dalam kalangan responden. Manakala peringkat seterusnya ialah pemilihan responden yang dilakukan secara purposif. Sebahagian responden adalah dari Fakulti Ekologi Manusia (50\%), manakala sebahagian lagi adalah dari Fakulti Sains $(50 \%)$. Responden terdiri daripada 37.2 peratus mahasiswa dan 62.8 peratus mahasiswi, yang berumur antara 20 hingga 29 tahun. Majoriti responden berbangsa Melayu $(n=221,94.4 \%)$, diikuti bangsa India $(n=7,3 \%)$, Cina $(n=2,0.9 \%)$ dan lain-lain $(n=4,1.7 \%)$. Dari segi pencapaian Purata Nilaian Gred Keseluruhan (PNGK), majoriti responden iaitu 86.6 peratus mencapai PNGK 3.00 hingga 3.749.

\section{Instrumen Penyelidikan}

Satu set soal selidik yang mengandungi empat bahagian digunakan dalam kajian ini untuk mengenal pasti dan mengukur maklumat latar belakang responden, sokongan sosial, penghargaan kendiri dan tahap kemurungan.

\section{Latar belakang Responden}

Maklumat latar belakang responden meliputi jantina, umur, kaum, fakulti, program pengajian, dan Purata Nilaian Gred Keseluruhan (PNGK). 


\section{Sokongan Sosial}

Sokongan sosial diukur menggunakan Multidimensional Scale of Perceived Social Support (MSPSS) oleh Zimet, Dahlem, Zimet dan Farley (1988). Instrumen ini mempunyai 12 item yang mewakili tiga dimensi sumber sokongan iaitu keluarga, rakan dan pihak lain yang penting. Instrumen ini menggunakan pemarkahan berdasarkan tujuh skala pilihan iaitu " 1 = sangat-sangat tidak setuju" hingga " 7 = sangatsangat setuju". Skor yang lebih tinggi menunjukkan persepsi yang lebih baik terhadap sokongan sosial yang diterima. Kebolehpercayaan bagi instrumen ini ialah 0.80 hingga 0.95 bagi ketiga-tiga dimensi sokongan sosial.

\section{Penghargaan Kendiri}

Penghargaan kendiri diukur menggunakan instrumen Rosernberg Self-Esteem Scale (RSES) yang dibangunkan oleh Rosernberg (1965). Instrumen ini mengandungi 10 item dengan pemarkahan berdasarkan skala empat pilihan iaitu dari " $1=$ sangat tidak setuju" hingga " $4=$ =sangat setuju". Kebolehpercayaan bagi instrumen ini ialah 0.90 .

\section{Tahap Kemurungan}

Tahap kemurungan diukur menggunakan Beck Depression Inventory II (BDI II) yang mempunyai 21 item penilaian diri yang mewakili simptom kemurungan seperti perasaan kesedihan, kegagalan, ketidakpuasan, rasa bersalah, tidak suka pada diri sendiri, pemikiran bunuh diri, kekerapan menangis dan lain-lain lagi. Skor bagi instrumen ini berdasarkan skala empat pilihan iaitu $0=$ Tiada; $1=$ Rendah; 2 = Sederhana; dan 3 = Tinggi. BDI II sesuai digunakan untuk golongan belia dan dewasa, dan mempunyai nilai kebolehpercayaan 0.93 .

\section{Analisis Data}

Data yang diperoleh dianalisis menggunakan Statistical Package for Social Science (SPSS 23). Statistik deskriptif digunakan untuk pemerihalan latar belakang responden dan pengukuran tahap sokongan sosial, penghargaan kendiri dan tahap kemurungan. Sementara itu, analisis inferensi yang digunakan adalah $t$-test untuk menguji perbezaan tahap kemurungan berdasarkan jantina dan program pengajian, korelasi Pearson untuk menguji hubungan antara pemboleh ubah dan regresi untuk menguji faktor peramal kepada kemurungan mahasiswa yang dikaji.

\section{Hasil Kajian dan Perbincangan}

\section{Tahap Sokongan Sosial Mahasiswa mengikutDimensi}

Berdasarkan Jadual 1, hasil analisis menunjukkan bahawa majoriti responden iaitu seramai 125 orang (53.4\%) mempunyai tahap sokongan sosial yang tinggi, dengan nilai purata $61.4(\mathrm{~S} . \mathrm{P}=15.87)$, diikuti responden yang mempunyai tahap sokongan sosial yang sederhana iaitu 90 orang (38.5\%) dan tahap sokongan sosial yang rendah iaitu 19 orang $(8.1 \%)$. Dari segi dimensi, sokongan sosial yang paling utama diterima oleh responden adalah daripada keluarga (purata $=21.21$; s.p. $=5.98$ ) diikuti sokongan daripada pihak lain yang penting (purata $=20.68$; s.p. $=6.15$ ) dan rakan-rakan (purata $=19.55$; s.p. $=$ 6.18). Secara keseluruhannya, tahap sokongan sosial mahasiswa bagi ketiga-tiga dimensi berada pada tahap yang tinggi.

Jadual 1 : Tahap Sokongan Sosial Mahasiswa mengikut Dimensi

\begin{tabular}{lcccccc}
\hline Pemboleh ubah & n & $\%$ & Purata & S.P & Min & Mak \\
\hline $\begin{array}{l}\text { Sokongan Sosial } \\
\text { Keseluruhan) }\end{array}$ & & & 61.44 & 15.87 & 19.00 & 84.00 \\
Rendah $(12-36)$ & 19 & 8.1 & & & &
\end{tabular}


DOI: https://doi.org/10.47405/mjssh.v5i11.54 7

\begin{tabular}{lcc}
\hline Sederhana $(37-61)$ & 90 & 38.5 \\
Tinggi $(62-84)$ & 125 & 53.4
\end{tabular}

\section{Dimensi Sokongan Sosial}

\section{Keluarga}

Rendah $(4-12)$

Sederhana $(13-21)$

Tinggi $(22-28)$
37

98
21.21

11.5

32.1

$132 \quad 56.4$

\section{Rakan-Rakan}

Sederhana $(13-21)$

Tinggi $(22-28)$
Pihak lain yang penting

Rendah $(4-12)$

Sederhana $(13-21)$

Tinggi $(22-28)$
$29 \quad 12.4$

$83 \quad 35.5$

$122 \quad 52.1$
15.8

41.9

42.3 $\begin{array}{llll}19.55 & 6.18 & 4.00 \quad 28.00\end{array}$

$20.68 \quad 6.15 \quad 6.00 \quad 28.00$

\section{Tahap Penghargaan Kendiri Mahasiswa}

Jadual 2 memaparkan tahap penghargaan kendiri responden. Didapati majoriti responden mempunyai tahap penghargaan kendiri yang sederhana iaitu seramai 161 orang $(68.8 \%)$ dan diikuti tahap rendah (29.1\%) dan tahap tinggi (2.1\%). Secara keseluruhannya, tahap penghargaan kendiri responden adalah sederhana di mana nilai purata skor bagi penghargaan kendiri ialah $16.60(\mathrm{~s} . \mathrm{p}=4.50)$. Skor maksimum yang diperoleh adalah 27, manakala skor minimum ialah 4.

Jadual 2 : Tahap Penghargaan Kendiri Mahasiswa

\begin{tabular}{lcccccc}
\hline Tahap & n & \% & Purata & S.P. & Min & Mak \\
\hline Rendah $(0-14)$ & 68 & 29.1 & 16.60 & 4.50 & 4 & 27 \\
Sederhana $(15-25)$ & 161 & 68.8 & & & & \\
Tinggi $(26-30)$ & 5 & 2.1 & & & & \\
\hline
\end{tabular}

\section{Tahap Kemurungan dalam kalangan Mahasiswa}

Hasil analisis yang dipaparkan dalam Jadual 3 menunjukkan bahawa majoriti responden berada pada tahap yang normal dan tidak mengalami kemurungan iaitu seramai 113 orang (48.4\%), diikuti 18.4 peratus responden yang mengalami tahap gangguan mood yang ringan. Seterusnya, 15.5 peratus responden mengalami tahap kemurungan yang sederhana, 7.7 peratus mengalami tahap kemurungan klinikal sempadan, 5.6 peratus mengalami kemurungan teruk dan 1.7 peratus mengalami kemurungan melampau. Secara keseluruhannya skor purata kemurungan responden yang dikaji adalah 13.28 yang menunjukkan responden mengalami gangguan mood yang ringan.

Jadual 3 : Tahap Kemurungan dalam kalangan Mahasiswa

\begin{tabular}{lcccccc}
\hline Tahap & n & \% & Purata & S.P. & Min & Mak \\
\hline Normal $(1-10)$ & 11 & 48.3 & 13.28 & 10.60 & 0.00 & 59.00 \\
Gangguan mood yang ringan $(11-16)$ & 3 & & & & & \\
& 43 & 18.4 & & & &
\end{tabular}


DOI: https://doi.org/10.47405/mjssh.v5i11.547

$\begin{array}{lcc}\text { Kemurungan klinikal sempadan }(17- & 18 & 7.7 \\ \text { 20) } & & \\ \text { Kemurungan yang sederhana }(21-30) & 35 & 15.0 \\ \text { Kemurungan teruk }(31-40) & 13 & 5.6 \\ \text { Kemurungan melampau }(40-60) & 4 & 1.7\end{array}$

\section{Perbezaan Tahap Kemurungan dalam kalangan Responden mengikutJantina dan Program Pengajian}

Hipotesis kajian yang dibentuk adalah tidak terdapat perbezaan yang signifikan tahap kemurungan yang dipersepsikan berdasarkan jantina (Ho1) dan program pengajian (Ho2). Analisis ujian-t sampel bebas telah digunakan untuk menentukan perbezaan tahap kemurungan dalam kalangan mahasiswa mengikut jantina. Hasil analisis yang dipaparkan dalam Jadual 4 menunjukkan bahawa tiada perbezaan yang signifikan bagi tahap kemurungan berdasarkan jantina (Purata lelaki $=21.71$, S.P. lelaki $=9.301$; Purata perempuan $=13.62$, S.P. perempuan $=11.310 ; \mathrm{t}=-0.623, \mathrm{p}=0.528$ ). Maka Ho1 diterima. Keputusan yang diperoleh selari dengan dapatan kajian Azizi et al. (2010) yang mendapati tidak terdapat perbezaan yang signifikan tahap kemurungan antara pelajar lelaki dan perempuan. Dapatan ini menunjukkan bahawa tahap kemurungan antara mahasiswa lelaki ataupun perempuan adalah tidak berbeza dengan masing-masing mempunyai nilai purata 12.71 dan 13.62 , iaitu berada pada tahap gangguan mood yang ringan.

Selain itu, kajian turut mendapati tiada perbezaan yang signifikan bagi kemurungan berdasarkan program pengajian (Purata BSPM $=12.85$, S.P. BSPM $=9.53$; Purata BSBDK $=13.71$, S.P. BSBDK $=$ 11.56; $\mathrm{t}=-0.616, \mathrm{p}=0.538$ ). Sama ada responden adalah pelajar jurusan sains sosial iaitu Bacelor Sains Pembangunan Manusia, mahupun sains iaitu Bacelor Sains Biologi dengan Kepujian, kedua-duanya berada pada tahap gangguan mood yang ringan. Maka Ho2 diterima.

Jadual 4 : Perbezaan Tahap Kemurungan dalam kalangan Mahasiswa mengikut Jantina dan Program Pengajian

\begin{tabular}{lccccc}
\hline & n & Purata & S.P & t(dk) & p \\
\hline Jantina & 87 & 12.71 & 9.301 & -0.6320 & 0.528 \\
$\begin{array}{l}\text { Lelaki } \\
\text { Perempuan }\end{array}$ & 147 & 13.62 & 11.310 & & \\
$\begin{array}{l}\text { Program Pengajian } \\
\begin{array}{l}\text { Bac. Sc. Pembangunan Manusia } \\
\text { (BSPM) }\end{array}\end{array}$ & 117 & 12.85 & 9.53 & -0.616 & 0.538 \\
$\begin{array}{l}\text { Bac. Sc. Biologi dgn. Kepujian } \\
\text { (BSBDK) }\end{array}$ & 117 & 13.71 & 11.56 & & \\
\hline
\end{tabular}

\section{Hubungan antara Sokongan Sosial, Penghargaan Kendiri dan Kemurungan dalam kalangan Mahasiswa}

Jadual 5 memaparkan hasil analisis korelasi Pearson untuk menguji hubungan antara sokongan sosial, penghargaan kendiri dan kemurungan dalam kalangan mahasiswa. Keputusan menunjukkan terdapat hubungan yang negatif secara signifikan antara ketiga-tiga dimensi sokongan sosial (keluarga, rakan, dan pihak lain yang penting) dengan kemurungan $(r=-0.391$ hingga $r=-0.510 ; p<0.001)$. Dapatan ini menunjukkan bahawa semakin tinggi sokongan sosial yang diterima daripada keluarga, rakan-rakan dan pihak lain yang penting, semakin rendah tahap kemurungan mahasiswa. Oleh itu, Hipotesis Ho3, Ho4 dan Ho5 yang menyatakan tidak terdapat hubungan yang signifikan antara sokongan sosial (keluarga, rakan-rakan, dan lain-lain yang penting) dan kemurungan adalah ditolak. Dapatan kajian ini mempunyai 
DOI: https://doi.org/10.47405/mjssh.v5i11.547

keputusan yang sama dengan dapatan kajian oleh Cheng (2003) dan Chang, Yuan dan Chen (2018) yang menunjukkan terdapat hubungan yang signifikan antara kemurungan remaja dengan sokongan sosial.

Selain itu, analisis juga menunjukkan hubungan yang signifikan secara negatif antara penghargaan kendiri dan kemurungan $(r=-0.501 ; p<0.001)$. Ini menunjukkan bahawa semakin tinggi penghargaan kendiri, semakin rendah tahap kemurungan. Oleh itu, Hipotesis Ho6 ditolak. Dapatan kajian ini selari dengan kajian yang telah dilakukan pengkaji lepas (Brown, Andrews, Harris, Adler \& Bridge, 1986; Khairul Bariah, 2003; Salsali \& Silverstone, 2003; Lee, Dickson, Conley \& Holmbeck, 2014) yang menunjukkan bahawa terdapat hubungan negatif yang signifikan antara penghargaan kendiri dan kemurungan. Penilaian yang positif dan baik kepada diri sendiri dapat mengurangkan tekanan dan seterusnya tahap kemurungan yang serius.

Jadual 5: Hubungan antara Sokongan Sosial dan Penghargaan Kendiri dengan Kemurungan dalam kalangan Mahasiswa

\begin{tabular}{lcc}
\hline Pemboleh Ubah & \multicolumn{2}{c}{ Kemurungan } \\
\cline { 2 - 3 } & r & p \\
\hline Sokongan Sosial & $-0.508^{* *}$ & 0.000 \\
Keluarga & $-0.510^{* *}$ & 0.000 \\
Rakan-Rakan & $-0.391^{* *}$ & 0.000 \\
Pihak lain yang penting & $-0.501^{* *}$ & 0.000 \\
Penghargaan Kendiri & & \\
\hline
\end{tabular}

\section{Faktor Peramal Kemurungan dalam kalangan Mahasiswa}

Analisis regresi berganda-stepwise telah dilakukan untuk menentukan faktor peramal kepada tahap kemurungan dalam kalangan mahasiswa. Rumusan Model dalam Jadual 6 menunjukkan tiga pemboleh ubah bebas yang menyumbang kepada kemurungan adalah penghargaan kendiri $(\beta=-0.301, p<0.001)$, sokongan sosial dari aspek keluarga $(\beta=-0.260, \mathrm{p}<0.001)$ dan sokongan sosial dari aspek rakan-rakan $(\beta=-0.177, \mathrm{p}<0.001)$. Nilai $\mathrm{R}^{2}$ iaitu 0.373 menunjukkan bahawa $37.3 \%$ kemurungan dijelaskan oleh tiga pemboleh ubah tersebut $[\mathrm{F}(3,230)=45.705, \mathrm{p}<0.001]$. Penghargaan kendiri adalah pemboleh ubah yang paling tinggi mempengaruhi kemurungan kerana mempunyai nilai $\beta$ yang paling tinggi, diikuti oleh sokongan sosial dari aspek keluarga dan sokongan sosial dari aspek rakan-rakan. Semakin tinggi penghargaan kendiri dan sokongan sosial daripada keluarga dan rakan-rakan maka semakin kurang atau rendah tahap kemurungan mahasiswa. Oleh itu, Ho7 ditolak.

Jadual 6 : Rumusan Model Analisis Regresi Stepwise bagi Penghargaan Kendiri dan Sokongan Sosial dengan Kemurungan

\begin{tabular}{|c|c|c|c|c|}
\hline Pembolehubah & B & Beta, $\beta$ & $\mathbf{t}$ & Signifikan, p \\
\hline Constant & 40.745 & & 16.710 & 0.000 \\
\hline Sokongan Sosial (Rakan-rakan) & -0.30 & -0.177 & -2.33 & 0.000 \\
\hline Penghargaan Kendiri & -0.709 & -0.301 & -4.93 & 0.000 \\
\hline Sokongan Sosial (Keluarga) & -0.461 & -0.260 & -3.62 & 0.000 \\
\hline $\begin{array}{l}\mathrm{R}=0.611, \mathrm{R}^{2}=0.373 \\
\text { Adjusted } \mathrm{R}^{2}=0.365 \\
\mathrm{~F}(3,230)=45.705, \mathrm{p}<0.001\end{array}$ & & & & \\
\hline
\end{tabular}




\section{Kesimpulan}

Kajian ini memberikan gambaran tentang tahap kemurungan dalam kalangan mahasiswa di universiti dan hubungannya dengan sokongan sosial dan penghargaan kendiri yang berperanan sebagai faktor pengaruh kepada kemurungan. Kajian mendapati majoriti responden berada pada tahap yang normal dan tidak mengalami kemurungan. Walaupun begitu, sebahagian responden menunjukkan mereka mengalami kemurungan pada tahap gangguan mood yang ringan, klinikal sempadan dan sederhana. Manakala, sebahagian kecil lagi responden mengalami kemurungan teruk dan melampau. Secara keseluruhannya, kajian menunjukkan hubungan yang negatif secara signifikan antara ketiga-tiga sumber sokongan sosial dan penghargaan kendiri dengan tahap kemurungan. Semakin tinggi sokongan yang diterima oleh mahasiswa sama ada sokongan daripada keluarga, rakan-rakan atau pihak yang penting akan mengurangkan kadar kemurungan mereka. Begitu juga dengan penghargaan kendiri yang semakin tinggi mengurangkan kadar kemurungan dalam kalangan mahasiswa. Dapatan juga menunjukkan sokongan sosial yang diterima daripada keluarga dan rakan-rakan serta penghargaan kendiri yang positif dan tinggi merupakan faktor pengaruh kepada kemurungan dalam kalangan mahasiswa. Justeru, dalam usaha mengatasi masalah kemurungan dan merangka intervensi yang sesuai kepada mahasiswa di universiti, faktor sokongan sosial dan penghargaan kendiri perlu diberi perhatian.

\section{Rujukan}

Aini, A. M, \& Haslinda, A. (2019). Kajian kes terhadap tahap kemurungan dalam kalangan remaja perempuan: Kupasan dan cadangan. Malaysian Journal of Youth Studies Edisi Khas YOURS'18, $135-152$.

Armsden, G. C., \& Greenberg, M. T. (1987). The inventory of parent and peer attachment: relationships to well-being in adolescence. Journal of Youth and Adolescence, 16, $427-454$.

Azizi, Y., Noordin, Y., Jamaludin, R. \& Siti Zainab, M. L. (2010). Kemurungan dalam kalangan penghuni rumah anak yatim di daerah Kota Bharu, Kelantan. Jurnal yang tidak diterbitkan (10127). Perpustakaan Universiti Teknologi Malaysia.

Brown, G., Andrews, B., Harris, T., Adler, Z., \& Bridge, L. (1986). Social support, self-esteem and depression. Psychological Medicine, 16(4), 813-831.

Chang, C. W., Yuan, R., \& Chen, J. K. (2018). Social support and depression among Chinese adolescents: The mediating roles of self-esteem and self-efficacy. Children and Youth Services Review 88, 128-134.

Chu, P. S., Saucier, D. A., \& Hafner, E. (2010). Meta-analysis of the relationships between social support and well-being in children and adolescents. Journal of Social and Clinical Psychology, 29, $624-645$.

Cohen, S., \& Wills, T. A. (1985). Stress, social support, and the buffering hypothesis. Psychological Bulletin, 98(3), 10-357.

Cornwell, B. (2003). The Dynamic Properties of Social Support: Decay, growth and staticity, and their effects of adolescent depression. Social Forces, 81(3), 953-979.

Costello, J., Pickens, L. M., \& Fenton, J. (2001). Social Support: A Matter Of Connections. Chicago, IL: Chapin Hall Center for Children at the University of Chicago.

Feshbach, S., Weiner, B., \& Bohart, A. C. (1996). Personality (4th ed.). Toronto: D.C. Heath.

Kementerian Kesihatan Malaysia. (2012). Kemurungan: Apa yang anda perlu tahu. http://www.moh.gov.my/moh/resources/Penerbitan/Rujukan/NCD/Kesihatan\%20Mental/Kemuru ngan_-_Apa_Yang_Anda_Perlu_Tahu.pdf

Khairul Bariah, K. (2003). Hubungan penghargaan kendiri dan kemurungan ke atas pencapaian akademik pelajar tingkatan empat. Projek ilmiah Sarjana Sains (Pengurusan Pendidikan) yang tidak diterbitkan. Sintok, Kedah: Universiti Utara Malaysia.

Lee, C. A., Dickson, D. S., Conley, C. N., \& Holmbeck, G. (2014). A closer look at self esteem, perceived social support, and coping strategy: A prospective study of depressive symptom atology across the transition to college. Journal of Social and Clinical Psychology, 33(6), 560-585.

Pertubuhan Kesihatan Sedunia (WHO, 2018). Depression. Retrieved from http://www.who.int/newsroom/fact-sheets/detail/depression 
DOI: https://doi.org/10.47405/mjssh.v5i11.547

Procidano, M. E., \& Heller, K. (1983). Measures of perceived social support from friends and from family: Three validation studies. American Journal of Community Psychology, 11, 1-24.

Rosenfeld, L. B., Richman, J. M., \& Bowen, G. L. (2000). Social Support Networks and Social Outcomes: The Centerality of the Teacher. Child and Adolescent Social Work Journal, 17(3).

Sherina, M. S., Nor Afiah, M. Z. \& Shamsul, A. S. (2003). Factors associated with depression among elderly patients in a primary health care clinic in Malaysia. Asia Pacific Family Medicine, 2: 148152.

Suriyani, Y., Fatahyah, Y. \& Aina Razlin, M. R. (2009). Hubungan antara perkahwinan dengan selfesteem. Jurnal Kemanusiaan, 13, 30-45.

Salsali, M., \& Siverstone, P.H. (2003). Low self-esteemand psychiatric patients: Part II - The relationship between self-esteem and demographic factors and psychosocial stressors in psychiatric patients. Annals of General Hospital Psychiatry. 2(1), 3.

Rosenberg, M. (1965). Society and the adolescent self-image. New Jersey: Princeton University Press.

Rosenberg, M (1979). Conceiving the self. New York: Basic Books.

Thapar, A., Collishaw, S., Pine, D. S., \& Thapar, A. K. (2012). Depression in adolescence. Lancet, 379(9820), 1056-1067.

Zheng, Y., \& Zheng, X. (2015). Current state and recent developments of child psychiatry in China. Child and Adolescent Psychiatry and Mental Health, 9, 10.

Zimet, G.D., Dahlem, N.W., Zimet, S.G., \& Farley, G. K.(1988). The multidimensional scale of perceived social support. Journal of Personality Assessment, 52, 30-41. 